yellow fever, bubonic plague, and other terrible scourges. We were glad to see portraits of Major Ronald Ross and other leaders in the campaign which science is waging on behalf of humanity, and especially on behalf of the native races of the tropical regions of the Empire. The evolution of the microscope is excellently demonstrated by the instruments lent by the Royal Microscopical Society, ranging from the copy of the simple microscope- of Leeuwenhock $(1675)$ to the 1848 pattern of Powell and Lealand. A full account of them may be found in Dr. Dallinger's editions of "Carpenter on the Microscope." Modern methods of mounting microscopical preparations are represented, also the processes for the preservation of anatomical structures on the larger scale.

Anthropology.-Anthropometric contrivances are numerous, and gain some additional interest from recent regulations with regard to the medical inspection of schools and from the efforts being made to secure an anthropological survey of Britain.

Geography and Geodesy.-The Government has given but little assistance to the science section as a whole, but in this division we find much instructive material lent by the War Office and the Board of Agriculture and Fisheries, the former through the topographical section of the General Staff and the latter through the Ordnance Survey. The production of the topographical map of the Orange River Colony is illustrated in all its stages, and there is a fine collection of Ordnance Survey maps of the United Kingdom. The Royal Geographical Society contributes photo reproductions of original MS. maps by British explorers in Africa, including Livingstone, Burton, and Speke. Surveying instruments used in famous preVictorian expeditions are to be seen, and also those of the latest 1908 pattern.

Geology and Geodesy.-The Geological Society shows facsimile reproductions of early tables and maps by William Smith, 1799 to I80t. Photographs of British scenery illustrative of geological features are contributed by the Geological Survey and the British Association Committee, of which Prof. Watts is secretary. We direct attention to a new small geological map of the United Kingdom, scale $I$ inch to 25 miles, published by the survey to provide teachers with a cheap and accurate map. In the palæontological division systematic research is illustrated by the grouping, viz. :- (a) collecting of fossils; (b) preparation of fossils; $(c)$ study of fossils; $(d)$ literary aids to research; $(e)$ presentation of results.

Oceanography.-The Admiralty has lent the gear used by H.M.S. Challenger, $1872-6$, photographic reproductions of Captain's Cook's original charts, and various pieces of apparatus used in sounding, both antique and recent. Biological specimens brought by the Scotia from the Antarctic can be seen, while the submarine cable companies contribute an attractive exhibit.

Meteorology.-No fewer than twenty-five pages of the catalogue are required for the enumeration of the items in this remarkably complete division. Here one may study the equipments of stations of the first, second, and third orders, and the methods of dealing with observations and results. Applications of meteorological statistics to agriculture and public health are instructively set forth. Apparatus for investigating the upper air, for observations on board ship, and for such special purposes as dustcounting, are on view. The historical collection includes Merle's weather journal, kept from $1337-44$, and the earliest treatise on the barometer, published in $x 688$. Photographs of lightning flashes and of cloud-forms are numerous and of high quality. In the subdivision devoted to terrestrial magnetism will be found the results of the Discovery Antarctic Expedition.

Astronomy.-Though placed last in the official classification, this section is second to none in extent and interest. The observatories of Greenwich Cape of Good Hope, Edinburgh, Cambridge, Oxford, Stonyhurst, and the Solar Physics Observatory of South Kensington have all contributed to a wonderful display of instruments and photographs. The subcommittee has arranged a stand to show the more important instruments required to equip a modern astrophysical laboratory. The large variety of objects of historical interest include an equatorial by Abraham Sharp (circa 1674), an astrolabe constructed for Sir Francis Drake, a Newtonian telescope made by W. Herschel, an Arabian astrolabe dated I224 A.D., and autograph letters of John Flamsteed relating to Greenwich Observatory in 1712. In an adjoining case we found a photograph of the new satellite of Jupiter, discovered by Mr. Melotte on February 28, 1908. We cannot imagine a better way to view the progress of astronomy during the last two centuries than by visiting this exhibition.

The National Physical Laboratory sends photographs and duplicates of apparatus used in standardising and research. Regarding such an exhibit as a gauge of the degree of advancement attained in the branches of knowledge for which the instruments are employed, and of the degree of skill reached by our manufacturing firms, we may feet legitimate pride in recent advances, particularly in electrotechnics.

In dealing with a new enterprise, it is, of course, easy to find details which are susceptible of improvement, but in this case the only faults we observed were minor ones, and will mostly disappear under the capable directors who have brought so large an undertaking to such a high pitch of attainment with commendable punctuality. We cheerfully omit minor criticisms, and express our strong feeling of indebtedness to the workers who have done so well. We also thank the executive of the exhibition for endowing the Science Section to the extent of about $7000 /$. The best return for this labour and generosity will be an attendance of visitors such as the merits of the exhibition deserve.

G. F. DANieli.

\section{CONFERENCE OF TEACHERS IN TECHNICAL INSTITUTIONS.}

THE second annual conference of the Association of Teachers in Technical Institutions was held in London last week. The following are among the matters of wide interest discussed at the conference :-

(I) The necessity for the provision of two types of schools for the continuance of the education of boys and girls from the ages of fourteen to seventeen years. The first of these types corresponds with the present existing firstclass "secondary" school, the second with the "trade" or "preparatory trade" school, which should be a secondary school with a marked " technical" bias. This school should prepare definitely for the trades, crafts, or industries.

(2) As a small but distinct educational advance, the minimum age of exemption from obligatory school attendance should be fourteen years, without any exceptions, as provided in clause 2 of the Education (Continuation Schools) Bill promoted by Mr. Chiozza Money. This; however, is only one step forward. The leaving age for trades, industries, or crafts, where the conditions of the trade permit, should be sixteen or seventeen years. From fourteen to sixteen years, the boy or girl should attend a school provided in accordance with paragraph (I) above.

(3) The technical institution has to deal with students who have received their preliminary training in the primary and secondary schools, often in the primary schools only. The average quality of the material from the primary and secondary schools is far from satisfactory; There is too often a certain lack of intellectual "grip" and thoroughness. How far this is due to the widening of the school curricula in recent years it is impossible to say. Signs are not wanting that in many schools the old evils of stringent individual examinations are being replaced by an evil almost as great, namely, the cramming of a number of pupils for the valuable borough and county scholarships now offered in such profusion. Technical colleges and schools have still to devote much valuable time, space, and equipment to work which should have been done in the secondary schools.

(4) In the case of a large number of students attending evening classes in technical schools, their sole previous educational training has been in the primary school up to the age of thirteen or fourteen years. About sixteen or seventeen years of age, or later, they enter the technical schools, after a period of three or four years during which

NO. 20I6, VOL. 78] 
they have failed to receive any systematic education. The remedy for this blank period lies in the continuation school. At present, however, the continuation schools, except in a few isolated cases like Manchester, Leeds, Bradford, and Birmingham, fail almost completely in this aspect of their work. This is particularly the case in London, where one of the many pressing questions is the improvement of the evening continuation schools and the correlation of the schools to the polytechnics.

(5) Technical institution teachers are, naturally, keenly interested in the Imperial College of Technology. They look forward to sending their best students (day and evening), by means of scholarships or bursaries, to this institution for the highest technical training and research. Judging by the present rate of progress, this will be impossible for a number of years. There is danger that, instead of the college being a " college of technology," it will merely be an organised group of institutions doing practically the same kind of work as that which is done in an ordinary university college. The governing body of the college needs to be brought more closely into touch with the main current of English technical education than it is, apparently, at present, in order that the work of the college may be properly coordinated with that of existing technical institutions. The "preliminary" work now being done in the college, which is done also by a considerable number of institutions all over the country, should cease at the earliest possible opportunity, and the whole energies of the college concentrated on the highest possible technical training and research. We need an institution which shall bear the same proportion to the Manchester Municipal School of Technology as the latter does to the technical institute of a small provincial town.

(6) There is a pressing need for the establishment of a common matriculation or school leaving examination for admission to all British universities, the professions, and the (day) technical colleges, in place of the multiplicity of examinations and examining bodies existing at present. Coupled with this is the need for a revision in the syllabus of some of the chief matriculation examinations as at present conducted.

(7) Reference was made during the conference to the scheme recently put forward by the King's College (London) authorities for instruction in "household economics," based upon a thorough introductory course of chemistry, physics, elementary bacteriology, physiology, \&c. While this would be undoubtedly beneficial in many ways, for example, in raising the status of "domestic science " teaching, it is felt by many technical institution teachers engaged in similar teaching in polytechnics and technical schools that the promoters of the King's College scheme have hardly done justice, in their preliminary publications and notices in the Press, to those engaged in such work in technical institutions. The impression given in these publications is that, up to the present, domestic science teaching has been empirical, "rule of thumb," and not based upon a knowledge of scientific " first principles." This is scarcely correct. For the last fifteen years the training schools of domestic economy attached to the polytechnics: and technical institutions have increasingly, year by year, laid stress upon attendance at compulsory courses of chemistry, elementary physics, theory of education, and in some cases elementary bacteriology.

\section{J. WILSON.}

\section{SOUTH-EASTERN UNION OF SCIENTIFIC SOCIETIES.}

THE thirteenth annual congress of the South-Eastern Union of Scientific Societies was held at Hastings on June 10-13.

Sir Archibald Geikie, K.C.B., F.R.S., who followed

Prof. Silvanus P. Thompson, F.R.S., in the presidential chair, took as the subject of his address "The Weald." $\mathrm{He}$ chose the subject because research in the problems connected with the Wealden area was eminently suitable for that combined action which local societies and field clubs are well fitted to provide. He spoke against the natural predisposition of the mind, in re-constructing the geo- graphy of former geological periods, to be too much influenced by the present grouping of sea and land. $\mathrm{He}$ sketched the part played by Godwin-Austen in the discovery of coal at Dover in consequence of his brilliant generalisation, after his profound study of the geology of N. France, Belgium, and S.-E. England (work which recalls, too, the names of Prestwich, Etheridge, and Boyd Dawkins). Having sketched the problem of the Palæozoic rocks, and having passed on to the deposition of the Purbeck and Wealden strata, he said that it was not easy to find the place whence the remnants of the terrestrial life of the Wealden deposits were derived, but indicated his belief that the crystalline and Palæozoic rocks of Brittany seem to be the greatly denuded core of an ancient land; for the Wealden deposits thin out rapidly in northerly, easterly, and westerly directions, and the only quarter which seems to offer itself as possibly that in which some vestige of the Wealden land may still remain lies to the south. Since the resources of modern petrography have armed the geologist of to-day with far ampler and more effective means of conducting the inquiry than his predecessors possessed, it would be well for some member of the union to undertake research into the origin of the pebbles found in the Ashdown Sand, the Wadhurst Clay, the Tunbridge Wells Sand, and occasionally in the Weald Clay.

The president sketched the various divisions of the Cretaceous rocks above the Weald Clay, emphasised the break between the Secondary and Tertiary periods, and then proceeded to discuss the evidences of the Ice age afforded by the Wealden area. Prestwich was disposed to think that the uplands of the Weald may have been a separate source of snow and ice, but he (Sir Archibald Geikie) did not think the evidence on which Prestwich relied was, perhaps, strong enough to warrant that conclusion. The decaying nature of the various rocks made observation of glaciation of the Wealden area difficult. But Prestwich may be right, and there may be other indications yet discoverable of "the traces of the Ice age in the Weald." I

The president also directed attention to the problem of the Coombe rock, and Mr. Clement Reid's ingenious solution of its origin, but thought that more directly convincing proofs of the. Ice age were to be found in the transported boulders-granite, syenite, and mica-schistfound in such numbers along the south coast from Worthing to Portsea, brought thither on floating ice. perhaps from the region of crystalline rocks in the N.W. of France. Before the Arctic conditions finally passed away, there appear to have been some alternations of milder seasons, and the time was further marked by oscillations in the relative levels of land and sea, indicated, on the one hand, by lines of raised beach, and, on the other, by submerged forests.

Mr. E. A. Martin read a paper on some considerations concerning dew-ponds, a subject on which he has been engaged some time, encouraged by a grant from the Royal Society. Mr. W. J. Lewis Abbott read a valuable paper on Pleistocene vertebrates of the S.E. of England, and conducted an excursion to all the salient geological features of the district, which, after eleven years' observation, he is well qualified to do. He considers the Hastings uplift the most important, and his paper will modify previous views on this important area. $\mathrm{Mr}$. Edward Connold contributed a paper on local sponges. which was a valuable contribution to this somewhat neglected branch of inquiry, and the same remark refers to Butterfield and Bennett's paper on the spider fauna of the Hastings district. Mr. W. H. Mullens discoursed on Gilbert White's connection with Sussex, and Mr. John Ray on mediæval timbered houses of Sussex and Kent. Mr. Wilfred Mark Webb touched upon a lighter theme in Darwinism as applied to dress, tracing the origin of some peculiar survivals in male and female attire.

Next year the meeting place will be Winchester, at the invitation of the Mayor and Corporation, and the president is to be Dr. Dukinfield Scott, F.R.S., president of the Linnean Society.

R. A. B.

1 Mr. Lewis Abhott supplied some in his naper on "Pleistocene Mammalia of S.E. England," subsequently read to the Congress.

No. 2016, VOL. 78] 